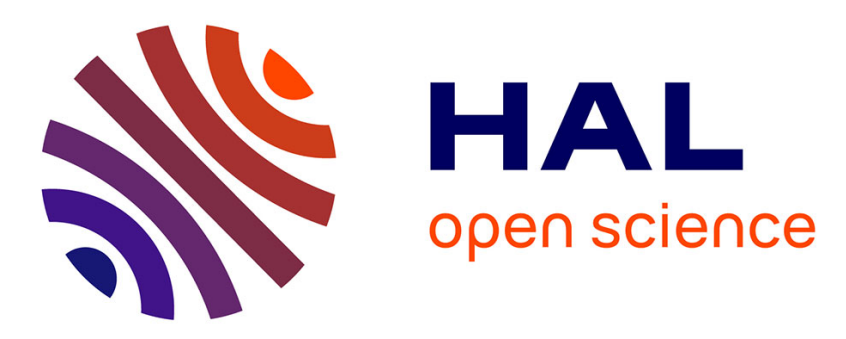

\title{
Inter-basin transfers as a supply option: the end of an era? \\ Jean-Daniel Rinaudo, Bernard Barraqué
}

\section{To cite this version:}

Jean-Daniel Rinaudo, Bernard Barraqué. Inter-basin transfers as a supply option: the end of an era?. Understanding and managing urban water in transition., p 175-200, 2015, 10.1007/978-94-017-98013_8. hal-01183852

\section{HAL Id: hal-01183852 https://hal-brgm.archives-ouvertes.fr/hal-01183852}

Submitted on 11 Aug 2015

HAL is a multi-disciplinary open access archive for the deposit and dissemination of scientific research documents, whether they are published or not. The documents may come from teaching and research institutions in France or abroad, or from public or private research centers.
L'archive ouverte pluridisciplinaire HAL, est destinée au dépôt et à la diffusion de documents scientifiques de niveau recherche, publiés ou non, émanant des établissements d'enseignement et de recherche français ou étrangers, des laboratoires publics ou privés. 


\section{Chapter 8}

\section{Inter-basin transfers as a supply option: the end of an era?}

Jean-Daniel Rinaudo \& Bernard Barraqué

\section{Introduction}

In the past, when water demand in large metropolitan areas outstripped local supply, additional water was often secured by tapping into other river basins. As a reflection of the enormous interests at stake, such economic centres devoted correspondingly impressive financial resources and technical ingenuity to the design and construction of inter-basin projects. Examples of projects transferring hundreds of millions of cubic meters per year over hundreds of kilometers abound in different parts of the world, including Australia, Europe, Northern and Southern America, and Asia. In the USA for instance, the largest metropolitan areas - including New York, Chicago, Los Angeles, Oakland and San Francisco, Houston, Dallas, and Miami - rely on large scale inter-basin transfers (IBTs). Most were built during the 19th and 20th centuries, reflecting a phase that Barraqué calls the civil engineering paradigm (see Barraqué et al, this volume).

The issue became more complex after WW2. On the one hand, under American influence, international finance institutions supported new-born nation-states, which, emerging from colonisation, endeavoured to develop their economies via hydraulic projects. On the other hand, in the US (and soon after in other developed countries), economic tools like cost-benefit analysis were increasingly used to legitimise projects funded from government and other sources. The idea that hydraulic projects should finance themselves via their beneficiaries slowly eroded the older 'pork barrel' philosophy. From about 1965, the environmental protection movement brought additional arguments against large hydraulic projects, and plans for many yet to be built began to be shelved since they seemed to perform poorly on both economic and environmental grounds. However, even today some projects still proceed, and indeed some large ones have emerged, as in China.

This chapter is devoted to discussing the evolving role of IBT in urban water management. We argue that the era of large IBT development is about to end, at least in democratic developed countries. The chapter starts with providing an historical overview of IBT development, distinguishing ancient drinking water aqueducts and multipurpose urban water projects. The next section describes how IBTs are challenged by a change in the technological and economic context. It shows how the emergence of alternative technologies, such as desalination, wastewater reclamation and reuse, or managed artificial groundwater recharge is reducing the attractiveness of IBTs. Water utilities are also becoming increasingly aware that water conservation programs can save volumes of water at a 
much cheaper cost than IBT. In section 4, IBTs are discussed within the changing socio-political context. We show, through various international examples, that IBTs trigger many questions and concerns from communities involved or affected, questions such as the environmental impact on donor and receiving river basins, the economic impact on donor regions, the impact on local cultures and livelihoods, how costs and benefits are distributed (social justice), and issues related to public participation. In a final section, we look ahead at new and more efficient uses of existing IBTs. We suggest they can be used for increasing the flexibility of how water is allocated over space and time. As conjunctive use management approaches gain support, IBTs will be operated in conjunction with aquifer storage and recovery schemes, and they will probably support the development of emerging water markets, in particular during drought years.

\section{IBTs in contemporary history}

Cities, and urban civilizations, have always depended upon fresh water. There are many examples of once glorious civilizations which disappeared due to changes in hydrologic conditions or extreme events (which they themselves sometimes provoked): Fatehpur Sikri, Angkor Wat, Mayan cities. Other cities were defeated when their conquerors destroyed their water supplies.

In most of these cases, water was required as a vital resource, but somewhat indirectly for irrigation and other human uses, including for drinking. More directly, with the Roman Empire for example, long distance aqueducts were developed primarily for urban comfort and drinking, since the amount of (pure) water carried was insufficient for irrigating crops. Most aqueducts ceased to function after the fall of the Roman Empire, and only a few small ones were built during the Middle Ages under feudal rule (monasteries). The one exception was Rome where a single aqueduct survived (Acqua Marcia, $91 \mathrm{~km})$.

The idea of acquiring clean, fresh water from a distance was picked up again by Italian engineers during the Renaissance. It was very much needed because at the time a proto-industry was being developed based, in part, on putrefaction techniques, the effect of which was to cause local urban water to become increasingly polluted (Guillerme 1983). Nevertheless, aqueducts were costly and reserved only for kings, their castles, and patrician palaces, although they would eventually come to serve public fountains. Most cities relied on local water sources, either wells or river water served by vendors.

During the 18th century water was increasingly considered a potential source of disease and even of epidemics (given the miasmatic theory). Experts of the time either favoured filtration, which was already experimented with, or distant sources. Before the discovery of microbes in the second half of the 19th century, there was no way to ascertain which of these two technologies was better. The choice was between small quantities of pure water from distant sources, or larger quantities of unsafe local water, which could be pumped thanks to the rapid spread of the steam engine at the turn of the XIXth century. Fire-fighting and parks watering also required water, and urbanization led to a dramatic increase in solid waste accumulation in the streets; many local authorities imagined they should 'wash the city clean', an option that required yet more water. 


\subsection{POTABLE WATER AQUEDUCTS}

Some of the aqueducts bringing water to palaces or monasteries, or even to public fountains, have long histories: the New River project in London dates to the 16th century and was $68 \mathrm{~km}$ long; the Medici aqueduct feeding the (now) Luxembourg palace in Paris from Rungis springs dates from 1623 and ran for $13 \mathrm{~km}$. In turn, progressive improvement in the technologies of pipe welding and faucet design allowed the development of water supplies under pressure, extending to within residential buildings. Enlarged water capacity was also needed to deal with waste evacuation, notably once London decided to turn the drainage system to the discharge of human waste. The combined sewer was born, and this innovation needed flushing if the slope was insufficient or the rain too infrequent.

In Britain, however, taking freshwater from distant sources was not easy for both hydrological and legal reasons: not only were there no large mountains or aquifers to draw water from, but the riparian rights, which translated the common law to the water domain, meant that cities needed an act of Parliament to catch distant water. Even though some cities like Glasgow managed to draw clean water from up to $55 \mathrm{~km}$ away (and as early as 1859), others preferred to take water from a nearby river and filter it. In London, filtration became mandatory in 1852 after a major cholera outbreak. Birmingham, the champion city for public water (and gas) procurement, had to wait until 1902 to get fresh water from a reservoir built in Wales 100 km away (Kraemer \& Barraqué 2012).

As early as 1837, New York decided to fetch water from Croton Lake, located north of Manhattan in a rural area about $60 \mathrm{~km}$ east of the Hudson river. A dam was built to store more water in the lake, and a $66 \mathrm{~km}$ aqueduct took water to a fountain in Manhattan in 1842. For centuries, Madrid in Spain had been served by groundwater, relying on the ancient Persian technology of the Qanats (horizontal galleries draining dripping groundwater). But in the 19th century, supplies became inadequate, and in 1851 a new aqueduct was built from mountains north-west of the capital, about $60 \mathrm{~km} \mathrm{away}^{1}$. In Paris in 1860, Baron Haussmann, a powerful Prefect of the time, found an engineer of the corps, Eugene Belgrand, who knew the nature of all the springs around Paris, and this engineer drew up a plan to divert several springs to Paris via a system of aqueducts that would take water from around $100 \mathrm{~km}$ away (Deutsch \& Gautheron 2012). It took almost a century for the plan to be fully implemented, but today these aqueducts provide half of the water Parisians drink, while Paris suburbs depend either on surface water from the Seine and its tributaries or from shallow aquifers.

Before the First World War, New York City extended its long distance aqueducts up to the Catskill mountains $250 \mathrm{~km}$ to the north. Other cities in the eastern part of the country, like Boston, also built in-stream storage facilities further and further away from urban areas. The first reservoir, Cochituate, built between 1845 and 1848, was only $27 \mathrm{~km}$ away, but the most recent, Quabbin, built in the 1930s, is $105 \mathrm{~km}$ away. The longest transfers can be found in California, most likely due to the Mediterranean-type climate. Around WW1, Los Angeles managed to appropriate freshwater from the Owens Valley and transferred it across a mountain range $(375+220 \mathrm{~km})$, while San Francisco built the Hetch Hetchy aqueduct from the Yosemite Mountains $(269 \mathrm{~km})$, and Oakland another line from the Moktelumne river $(153 \mathrm{~km})$. Some time later, Southern California even took water from the Colorado River $389 \mathrm{~km}$ away across a range of mountains.

\footnotetext{
${ }^{1}$ See "The Croton Aqueduct", New York Historical Society at https://www.nyhistory.org/seneca/croton.html
} 
In Europe, construction of long distance transfers usually depended upon authorisations, and they required subsidies or low interest loans by national or central governments, the reason they were frequently reserved for capital cities. Lyon, the second largest city in France, always took its water from an alluvial aquifer in a natural area upstream of the Rhone. Conversely, Lisbon received water from a reservoir upstream through a magnificent aqueduct (Aguas Livres) built by the government in the 19th century, an aqueduct which incidentally provides little water compared to the needs of modern hygiene (Schmidt 2012). As soon as water treatment could take advantage of discoveries in microbiology, it became cheaper to provide safe water pumped from rivers close to cities, and many aqueduct projects became financial white elephants.

But of course, water transfer projects were still being built throughout the Mediterranean and in other areas of water scarcity. In France, the Canal de Marseille is an $80 \mathrm{~km}$ transfer from the Durance, providing water to Marseille as early as 1849 , but which was constantly improved until 1970, when it was supplemented with a regional water scheme called Canal de Provence ${ }^{2}$. Another example is the Landeswasserversorgung in Baden Württemberg, a complex system of aqueducts from the mountains in the south to the urbanised north (in the Stuttgart area). It was a national project funded and owned by the German government in the early 20th century, and it was only after WW2 that it was transformed into an inter-municipal joint board ${ }^{3}$. The most impressive example in Europe between the two World Wars remains the Italian Aquedotto Pugliese ${ }^{4}$, a regional scheme to bring water to the driest part of the country (the heel of the boot), and which has long been the largest regional water supply scheme in terms of population served (4.5 million).

\subsection{MULTIPURPOSE PROJECTS AND URBAN INTERBASIN TRANSFERS}

In the early 20th century, the increasing involvement of national states in economic matters led to an unprecedented rise of large hydraulic projects, including dams and transfers, and this time it was not only to bring water to cities. Projects usually started with hydroelectricity generation, requiring the construction of reservoirs. But then it also became conceivable to regulate river flows so as to enlarge navigability periods, provide water for irrigation, and for industry. Eventually such projects also included water for cities, but it was not their main goal.

The United States played a major role in this development, the reason being that they could mobilise important major amounts of capital and direct them to areas that were wild or even desert. One of the first projects was the construction of a canal from the Colorado to the Imperial Irrigation District, a desert located between San Diego and the Mexican border (1898). This project was followed by many other state or federal projects, resulting in the interlinking of Californian watersheds and valleys from north to south ${ }^{5}$. Today, more than three-quarters of the water is used for irrigation, and progress in water efficiency has created the opportunity to re-allocate water for other higher value uses.

Similar projects were constructed in several western states, in particular in Colorado and Arizona. The city of Denver, Colorado, which is located on the eastern slopes of the Rocky Mountains, put in place a long distance infrastructure to convey water from the western side of the range. As a

\footnotetext{
${ }^{2}$ See the Canal de Provence website at http://www.canal-de-provence.com

${ }^{3}$ See website of Landeswasserversorgung - Trinkwasser für Baden-Württemberg at http://www.Iw-online.de/

${ }^{4}$ See the Aquedotto Pugliese website at www.aqp.it

${ }^{5}$ See the Californian Department of Water Resources at www.water.ca.gov
} 
compensatory measure for people in areas from where the water came, reservoirs reserved for their sole use were also constructed (Blomquist et al., 2004).

In Arizona, the development of the Colorado Aqueduct Project was mainly intended to supply the rapidly growing areas of Tucson and Phoenix, which had outgrown local surface water and groundwater resources. As is frequently the case with multipurpose projects, the transfers were mainly paid for by urban users, with additional water sold to farmers at a much lower price.

However, the most representative example of this multipurpose project policy is to be found in the eastern United States: the Tennessee Valley Authority. This was a planned project to revitalise a depressed economic area after the 1929 crisis. It was also a federal government project to create a dream in which water mobilisation could create a new and modern way of life (with electricity for industry and homes). At the time, there was a similar project planned on the Rhone in France (CNR), but engineers and planners met strong resistance from local communities and the project remained limited to electricity generation on the Rhone between Switzerland and Lyon (the Génissiat dam). Similarly, the soviet regime built a similar project on the Dniepr under Stalin (the Goelro plan, with the Dnieprostroi hydroelectricity farm and education centre).

The allied victory in 1945 led to the setting up of a new world order based upon the creation of new nation states. These new states were encouraged to promote economic development through the development of hydraulic infrastructure. American cooperation was influential, and the TVA is still considered to as an inspiring model, as this quote from the TVA website indicates:

Under the leadership of David Lilienthal ("Mr. TVA"), the Authority became a model for America's governmental efforts to modernize Third World agrarian societies. ${ }^{6}$

Many countries launched hydraulic projects combining electricity generation, irrigation, and urban water supply, as did Spain with the financial support of the US (Swyngedouw 1999). During the Franco dictatorship (1940-75), Spain became, in terms of number of dams, the third highest-ranking country in the world. Brazil also developed complex water and electricity projects in the metropolitan areas of Sao Paulo and Rio de Janeiro, and later with huge dams on the Parana. Even small countries like Israel ${ }^{7}$ or Tunisia $^{8}$ built national water carriers for the sake of developing arid southern regions. Socialist countries also invested in large projects, with the USSR developing some in central Asia for cotton growing (the Ferghana valley in Uzbekistan). This project led to the drying up of the Aral Sea, because the part of the scheme which involved changing the course of a Siberian river southwards to feed the dying sea could not be built. In many developing countries, however, multipurpose schemes were legitimised by appeals to the need for urban water, even if this need remained minor.

Despite growing doubts about the positive balance of pros and cons, and the retreat of the World Bank on several financing schemes, many of these projects went ahead: GAP (the Greater Anatolia project) in Turkey, Nile regulation with Toshka transfer in Egypt, the Three Gorges and South-North transfers in China, and the San Francisco-Ceara in Brazil. India is even now considering the

\footnotetext{
${ }^{6}$ Tennessee Valley Authority website at www.tva.gov

${ }^{7}$ See presentation of the National Water Carrier at http://www.mekorot.co.il/Eng/Mekorot/Pages/IsraelsWaterSupplySystem.aspx

${ }^{8}$ See website of the Tunisian National Water distribution society at www.sonede.com.tn/index.php?id=44
} 
construction of project linking rivers in the Himalayas to Kerala and Tamil Nadu, with eastern and western branches.

After the rise of the environmental movement in the 1970s, multipurpose hydraulics started to receive criticism, beginning in the US, from ecologists and also economists. In France, the retreat of hydraulic engineers from the colonies gave rise in the 1960s to the development of new multipurpose projects at regional level. Three major regional planning companies were set up: Société du Canal de Provence, Compagnie du Bas-Rhone Languedoc, and Compagnie d'Aménagement des Côteaux de Gascogne. All of these started with irrigation as a major component, but Canal de Provence was more economically successful because it found urban and industrial customers able to pay close to the full cost of regional water.

It was the rise of alternative solutions for urban water provision which undermined the economic rationale of IBTs.

\section{IBTs in a changing technological context}

Until the late 1980s, water transfers were often the sole technological option cities could rely upon to supplement local resources and meet fast-growing demand. The emergence of alternative technologies, such as desalination, wastewater reclamation and reuse, or managed artificial groundwater recharge - and the progressive decrease of their cost - strongly influenced the perception of IBTs by water managers and planners. At the same time, water utilities increasingly became aware that the demand for water could be curbed through proactive water conservation policies. Because significant volumes can be saved and devoted to new uses, water conservation has increasingly been considered as an alternative to water supply options - IBTs in particular. This section aims to illustrate how this change has happened through examples selected from different parts of the world.

\subsection{THE DEVELOPMENT OF NON-CONVENTIONAL SUPPLY OPTIONS}

\section{- IBT versus desalination}

Desalination represents a serious alternative to inter-basin transfer for a number of reasons. The first one is the declining cost of this water supply option. The most common technology chosen for new desalination plants today is reverse osmosis ( $60 \%$ of existing capacity), in which salt water is filtered under high pressure through semipermeable membranes. The cost of RO varies significantly depending of the quality of raw water used, the size of the plant, the site conditions, and the cost of energy (Zhou and Tol 2005; Ghaffour et al. 2013). Desalination of brackish groundwater, estuarine water, or contaminated fresh water is often preferred to seawater desalination due to reduced energy cost. Recent case studies have shown the full cost of such projects ranges between €0.3-0.7 $/ \mathrm{m}^{3}$ (Vedachalam and Riha 2012). A Spanish study estimated the cost of seawater desalination at about $€ 0.7 / \mathrm{m}^{3}$ in the Segura basin, when facilities there operate at full capacity (Lapuente 2012). These costs are likely to continue to decrease if new low-energy technologies become successful (Ghaffour et al. 2013). 
There are other reasons why desalination can be more attractive than IBTs for water utility managers. The prime advantage of desalination is that it is a secure and reliable source of supply, independent of climatic conditions, unlike IBTs which can be affected by drought. Desalination also produces very high water quality that can be blended with lower quality water supplies if necessary. For local politicians, desalination offers greater control of municipal water supplies, allowing them to freely consider a wide range of economic developments - without depending on water supplies from outside their jurisdiction. Last but not least, the mobilisation of financial resources is easier in the case of desalination as the private sector often gets involved through 'build-own-operate-transfer' (BOOT) contracts (Ghaffour et al. 2013). Since the associated costs are operational and maintenance costs rather than initial investment, they are easier to recover from customers, even if they are high. In comparison, IBTs have always been associated with cheap water because in fact they were heavily subsidised.

Several large metropolitan areas confronted with mounting water scarcity (and even shortages during droughts) have preferred the desalination option rather than the construction of an interbasin transfer. The case of Barcelona provides a good illustration. In the 1990s, Barcelona investigated the possibility of importing water from the Rhône river, through an extension of the canal system that diverted water to the Montpellier region. The project consisted in constructing a 330 kilometers long pipeline intended to transfer up to 400 million $\mathrm{m}^{3} / \mathrm{yr}$ to the metropolitan area. For reasons that will be further exposed below, the metropolitan area instead constructed a 200,000 $\mathrm{m}^{3} /$ day brackish groundwater desalination plant in 2009 which now satisfies $20 \%$ of Barcelona's drinking water needs (Sauri 2012).

Another example is the Kimberley pipeline scheme designed to supply Perth in Western Australia (Ghassemi and White 2007). Metropolitan Perth has a sustained population growth of over $1.5 \%$ per year and it is expected that demand could increase by 600 million $\mathrm{m}^{3} / \mathrm{yr}$ by 2050. In that context, numerous proposals have been developed since the late 1980s to transfer water from the wet tropical region of the Kimberleys to Perth and even Adelaide (op. cit. pp. 169-176). The preferred project consisted in constructing a $1400 \mathrm{~mm}$ diameter pipeline 1,840 to 2,100 km long (depending on route). Investment cost was estimated at A\$8-11 billion (1990 dollars) and operating and energy costs were more than $A \$ 2$ billion/yr. Overall, the total cost of imported water was estimated at $A \$ 5-$ $6 / \mathrm{m}^{3}$, which was five times above the cost of desalinated water $\left(A \$ 1.1 / \mathrm{m}^{3}\right)$ and other alternative options such as groundwater extraction (A\$0.3-0.8)). After several studies, the Kimberley scheme was finally abandoned and a 45 million $\mathrm{m}^{3} / \mathrm{yr}$ desalination project was approved in 2003 at a cost of A $\$ 350$ million. The Western Australian government also adopted a strategy of improving water use efficiency in all sectors and promoting water reuse.

\section{- IBT versus wastewater reclamation and reuse}

Another alternative to IBTs consists in using poorer quality water supplies and developing wastewater treatment (reclamation) for subsequent use as a water supply (reuse). Water reuse is growing in importance in the US, Australia, some parts of Asia (Singapore), and in Western Europe (Spain). Recycled water is most commonly used for groundwater replenishment or for landscape irrigation; much less frequently is it used for direct domestic reuse.

Reclamation and reuse can be either centralised or decentralised. In decentralised systems, water reclamation facilities are located close to areas where commercial or residential demand exists for 
reclaimed water. Only a fraction of the available wastewater is treated and distributed. This approach, which is sometimes referred to as "sewer mining" only requires the development of a small local secondary distribution network. Investment saving are likely to compensate the cost of no economy of scale.

In a centralised system, wastewater is collected and treated (possibly up to drinking water standards) before being introduced into a water supply source (river, reservoir, or aquifer). A combination of three purification technologies is frequently used: micro-filtration, reverse osmosis, and UV treatment (Zekri et al. 2013). A well-known example is the groundwater replenishment program of Orange County Water District (OCWD) in California. OCWD has recently completed a new recycling facility that provides a new resource for the region. Wastewater is treated using reverse osmosis technology. It is then injected into the aquifer through a series of shallow and deep wells. The system is used both as a seawater intrusion barrier and a source of water. Groundwater is then pumped and used for drinking supply (indirect potable reuse) and distributed to consumers using the existing reticulation system. A variant, observed in other Californian water districts (see Chapter 11 on demand forecasting, this book), consists in directly distributing reclaimed water to customers through a dedicated reticulation network ('purple pipe') for non-potable use. The cost of this option is much higher due to the need to construct a dual distribution network. In Europe, the Dutch have long replenished the sand-dune aquifer between the Ranstad and the North Sea with monitored freshwater from the Rhine (when the quality is acceptable). In Barcelona, the AGBAR company also treats waste water through RO technology to recharge the alluvial aquifer of the Llobregat $15 \mathrm{~km}$ upstream from the drinking water plant of Sant Joan Despi.

A number of studies have shown that the costs of managed artificial recharge and water reclamation compare favorably with those of alternative sources. In California, the total capital, operating, and maintenance costs were estimated at US\$1.34/ $\mathrm{m}^{3}$ for the West basin and US\$0.77 for Orange County Water District, which is cheaper than imported water supplied by the Metropolitan Water District of Southern California (National Academy of Sciences 2012). In San Diego, the cost of recycled water is estimated at about $€ 0.35 / \mathrm{m}^{3}$ (2001 value) which is equivalent to $90 \%$ of the potable water cost. The same results were found in Florida where the cost of recycled water was estimated at $€ 0.3-0.37 / \mathrm{m}^{3}$ (Miller 2006). Other comparable cost figures are reported for several projects worldwide (Zekri et al. 2013).

Recycled wastewater can also be introduced into surface water resources. Singapore opted for this option with the well-known NEWater project in the early 2000s. Wastewater is treated and blended with surface water resources in reservoirs. Recycled water will represent $15 \%$ of daily urban consumption once the planned treatment capacity is fully deployed. This technological change was implemented with the aim of reducing reliance on importing water from Malaysia. The cost of NEWater is estimated at less than $€ 0.2 / \mathrm{m}^{3}$ (Tortajada 2006).

\subsection{IBTS VERSUS WATER CONSERVATION}

Although urban water utilities are still inclined to consider importing remote new resources to satisfy the needs of growing populations and economies, they are increasingly aware that the demand for water can be curbed through proactive water conservation policies, which often turn out cheaper than new water supply schemes. A projected transfer from Sweden to Denmark across the Sund was abandoned after Copenhagen drastically reduced its domestic water consumption. In the UK, the 
regulator Ofwat banned water transfers from the north to the London area until water conservation measures were implemented to reduce leakage. In southern Italy, the Aquedotto Pugliese looked at the option of importing water from Albania across the Otrante Strait. But water conservation policies made this project unnecessary, as well as other, smaller and less fancy IBTs.

There are a number of benefits associated with water conservation: containing demand avoids or postpones huge capital costs associated with the expansion of water supply and waste water treatment infrastructure. A number of studies have shown that reducing water demand through active water conservation measures can be much cheaper than mobilising new conventional or nonconventional resources. In California, a study by the Pacific Institute estimated that more than $25 \%$ of existing water use could be saved at a cost below the marginal cost of water supply (Gleick et al. 2003). Similar results were found in southern France (Rinaudo et al. 2010).

Three main control levers can be used to promote urban water conservation. The first one consists of imposing minimum technical (or economic) water efficiency standards that water utilities need to comply with. This particularly applies to water distribution networks, which are still often characterised by high rates of leakage. Leakage can be reduced by setting up a technical and managerial organisation that allows for real-time detection of pipe bursts or leakage and rapid repair. It also requires increasing the replacement rate of old pipes, which can entail huge costs, especially if maintenance has been deferred for many years. Different regulatory approaches can be selected. France for instance has opted for the definition of maximum admissible rates of leakage based on technical criteria such as the number of customers per pipe kilometre (regulation of 27 Jan 2012). A different approach is implemented in the UK where water companies are required to calculate an economically optimal level of leakage (ELL), which is such that the marginal cost of reducing leakages equals the marginal cost of mobilising new resources.

The second tool consists of economic incentives to promote the adoption of water-efficient technologies. Two types of incentives have been widely used in the USA and more recently in Australia: price rebates, and water conservation oriented water rates. Rebate policies aim at encouraging the purchase of water-efficient appliances (e.g. AAA clothes washing machines, timers for garden sprinklers) or retrofitting of old inefficient appliances (toilets). Rebates can target domestic, commercial, or industrial users. European countries are making tentative attempts at using them. Pilot projects have been implemented in the UK (Waterwise 2009), Spain (Shirley-Smith et al. 2008), and in some French counties (Corrèze, Gironde) through distribution of free or subsidised faucet aerators or 'water hippos' (bag-like devices that fit in the water cistern and reduce the volume of water flushed).

Water conservation oriented rates have also been used to promote the wise use of water. Pricing tools are intended to simultaneously change water use behaviour (reduction of wastage) and promote the adoption of water-efficient appliances, fixtures, and fittings. The most frequently used tariffs are increasing block rates and seasonal rates. A number of studies have demonstrated the potential savings that can be achieved through such tariffs (Rinaudo et al. 2012). More complex budget-based rates are also becoming more popular in south-western states of the US. This approach consists of rates that are tailored to the situation of individual customers. ${ }^{9}$ In Europe, this rate

\footnotetext{
${ }^{9} \mathrm{~A}$ water budget rate is an increasing block rate structure in which the block definition is different for each customer, based on an efficient level of water use by that customer (Mayer et al. 2008, quoted in Beecher 2012).
} 
budgeting is not frequent, but some water companies in England propose variable tariffs, with either high fixed parts and low volumetric prices (for customers who have regular water uses) or low fixed parts and high volumetric ones (for people who may have low consumption but some peaks). However, experienced economists of applied water regulation suspect that these smart tariffs end up having paradoxical and 'disconcerting' effects (Beecher 2012).

The third lever consists of raising customer awareness of water scarcity through information campaigns. This lever is often considered as a catalyst for and used in conjunction with technical and incentive-based measures. A few econometric studies have shown that they can, for instance, significantly enhance the effectiveness of water pricing measures (Kenney et al. 2008).

Water conservation may also generate significant benefits related to energy savings. In the residential sector, these benefits may outweigh the cost of installed devices such as low flow showerheads or high efficiency washing machines and dishwashers.

\subsection{ECONOMIC COMPARISON OF IBTS WITH ALTERNATIVE SOLUTIONS}

In developed countries, water utilities are increasingly compelled by regulators to justify that the investment decisions they make are economically sound. This often implies conducting costeffectiveness or benefit-cost analyses ${ }^{10}$ to compare various water supply and demand management options. Inter-basin transfer projects must be compared not only to 'soft' water conservation measures (Gleick 2003) but also to alternative 'hard' water supply options, including desalination and waste water reuse. The economic comparison of alternative water management options is current practice in the US, where least-cost and benefit-cost analyses generally make up a full chapter of urban water management plans. It is also increasingly used in Europe, partly because the Water Framework directive requires it, but also because national regulators like Ofwat and the Environmental Agency in the UK (EA 2012) have made it compulsory. Many case studies have shown that water conservation measures and the use of non-conventional resources can be much cheaper than long-distance and large-scale inter-basin transfers. They might not, however, always be sufficient to bridge the increasing gap between demand and supply in regions confronted with rapid demographic and economic growth. This will be illustrated through references to several international situations.

\section{- Results of economic assessment in selected examples}

In the UK, a systematic cost-effectiveness analysis of water supply and water demand management options is carried out for all water resources management plans (WRMPs) prepared by water companies, according to guidelines developed by Ofwat and the Environmental Agency. The EA states that the WRMP assessments have demonstrated that large-scale transfers of water to the south of England from Wales or the north of England would be more expensive than other options available to meet current forecast demand (Environment Agency of England and Wales 2011).

\footnotetext{
10 The cost-effectiveness approach consists in calculating the average annual cost of each cubic meter saved (or mobilised) with a set of water supply and water conservation measures. Annual costs are calculated by spreading investment costs over a duration corresponding to the technical lifespan of the project and adding recurring operational and maintenance costs. Diminishing effectiveness (in terms of volumes saved) can be accounted for in the calculation if relevant. The benefit-cost approach consists in estimating the costs and benefits of a set of water conservation measures that can be ranked and prioritised on the basis of a benefit-cost ratio. This approach has been widely used in the US, in particular because it was incorporated in software packages such as IWR-MAIN developed by the Army Corps of Engineers, or the Least Cost Planning Demand Management Decision Support System developed by Maddaus (Maddaus and Maddaus 2004).
} 
In the Spanish Catalonia region, Pouget et al. (2012) conducted a cost-effectiveness analysis to compare various adaptation strategies. Their study shows that long-distance inter-basin transfer (bringing water from the Rhône in France to Barcelona) would cost up to five times more $\left(€ 0.5 / \mathrm{m}^{3}\right)$ than water conservation in agriculture (modernisation of irrigation systems) or implementing seasonal tariffs $\left(€ 0.1 / \mathrm{m}^{3}\right)$. Other water supply measures were also found to be less expensive than large inter-basin transfer projects, e.g. managed aquifer recharge $\left(€ 0.25 / \mathrm{m}^{3}\right)$, improvements in the quality of currently polluted water resources $\left(€ 0.25 / \mathrm{m}^{3}\right)$, and water reuse projects $\left(€ 0.3 / \mathrm{m}^{3}\right)$. However, in the long term these measures would not be sufficient to bridge the gap between future water demand and available resources, as the latter would decline due to climate change. The mobilisation of new resources, through a transfer from the Rhône or desalination (the option which Barcelona ultimately chose), would thus be necessary. In our opinion, many studies of water demands are based on unquestioned optimistic demographic and economic growth forecasts, and this was indeed the case for the Barcelona water transfer justification.

Examples can also be found in Australia. Table 2 below emphasises the relevance of water saving measures in the Australian Canberra area.

Table 2: Levelised costs by water management options for the Canberra area (Turner and White 2003)

\begin{tabular}{|l|r|r|r|}
\hline Option & $\begin{array}{c}\text { Savings in } 2023 \\
\left(10^{3} \mathrm{~m}^{3} / \mathrm{a}\right)\end{array}$ & $\begin{array}{r}\text { Present value cost } \\
(\mathrm{M} \$)\end{array}$ & \multicolumn{2}{|c|}{$\begin{array}{c}\text { Levelised cost } \\
\left(\$ / \mathrm{m}^{3}\right)\end{array}$} \\
\hline Water conservation & 12,500 & 45.2 & 0.30 \\
\hline Source substitution & 6,000 & 308.5 & 4.50 \\
\hline Source augmentation: & & & 1.45 \\
-New cotter dam & 3,700 & 55.6 & 1.34 \\
-Tennent & 3,700 & 77.4 & 1.87 \\
-Tantagara & 3,700 & 47 & 1.14 \\
\hline
\end{tabular}

\subsection{IBTS VERSUS MORE GRADUALIST ADAPTABLE SOLUTIONS}

Due to the one-off nature and very long lifespan of IBT infrastructure, its design calls for a forecast of the long-term demand in the receiving basin and the long-term water resources availability in the donor basin. However, over the last decade we have seen how large are the uncertainties attached to demand and supply figures, and how difficult it is to forecast them accurately. Climate change in particular makes it difficult to predict the amount of water which will be available in both the receiving basin (local resources) and the basin of origin. New water infrastructure must be able to meet a large range of changing conditions. In that context, some authors recommend avoiding the use of large inflexible infrastructure which can't adapt to changing climatic or economic conditions (Hallegate 2009). Instead, they recommend adopting a gradualist strategy, reducing the time horizon for decisions and adapting management strategies as the situation unfolds. Such flexible approaches necessarily involve a combination of various infrastructure solutions (storage, transfer, recycling) and soft adaptation strategies (demand management).

In some countries, these recommendations have already been transferred into regulations. These impose an approach which combines infrastructure development with water conservation and recycling. This is the case for instance in California, England, and Wales. Moreover, cities which 
depend heavily on imported water supplies tend to invest in multiple alternatives so as to reduce their vulnerability to interruption of their major resource. This is true for cities subject to earthquakes, like Marseille in France or in California. The solution consists in developing local resources (groundwater in Marseille, the Encina desalination plant in San Diego) and implementing water demand management approaches (including setting the water price at the potential marginal cost in case a new supply is built).

\subsection{ENERGY CONSIDERATIONS}

Since IBT projects often require moving large quantities of water over long distances and significant elevation differences, they are high energy-consuming water supply options. For instance, the energy used by the California State Water Project (SWP) to transfer water from north to south California represents about 2 to $3 \%$ of all electricity consumed in the state. This is equivalent to approximately one-third of the total average household energy use in the region (Cohen et al. 2004). With this perspective, non-conventional water supply options such as desalination of brackish water or reuse may be competitive in terms of energy requirements. For example, the water recycling system constructed in Orange County, southern California, uses only half the energy required to import water from Northern California with the SWP (Cohen et al. 2004). In a context of increasing concern over energy issues, the high energy requirements of IBT are likely to reduce their attractiveness against other technological solutions.

\begin{tabular}{lr}
\hline Current water sources of supply & \multicolumn{2}{l}{$\begin{array}{l}\text { Electricity use } \\
\text { (kWh/acre foot) }\end{array}$} \\
\hline $\begin{array}{l}\text { State Water Project: transferring } \\
\text { water from San Francisco Bay }\end{array}$ & 3200 \\
Delta & \\
\hline Colorado River Aqueduct & 2000 \\
\hline Local groundwater & 570 \\
\hline $\begin{array}{l}\text { Ocean water desalination } \\
\text { (Encina) }\end{array}$ & 4200 \\
\hline Additional water supply sources & 2110 \\
\hline $\begin{array}{l}\text { Purchase and transfer from } \\
\text { Imperial Irrigation District }\end{array}$ & 1800 \\
\hline Recycling & 2240 \\
\hline Additional State Water Project
\end{tabular}

\section{IBTs in a changing socio-political context}

IBTs trigger many questions from communities affected. These questions involve a variety of issues including environmental impacts on donor and receiving river basins, the economic impact on donor regions, impact on local cultures and livelihoods, how costs and benefits are distributed (social justice), and issues related to public participation (Gupta and van der Zaag 2008). 


\subsection{A GROWING CONCERN FOR ENVIRONMENTAL AND SOCIO-ECONOMIC IMPACTS OF IBTS}

\section{- Environmental concerns}

There is a growing awareness that IBTs can generate significant environmental impacts on donor and receiving basins. In the donor region, reduction of in-stream flow may endanger aquatic ecosystems through reduced flows, which results in increased temperature and reduced dilution of pollutant loads discharged to rivers. Receiving regions can also be impacted by the inflow of imported water. Ecosystems or species can be perturbed by changes in the hydrological regime of the receiving river, or by its quality. There are examples where an IBT has favored undesirable migration of species from one basin to another and even of invasive alien species. IBTs also modify hydrological regimes, reduce flow variability, and can cause a seasonal river to become a perennial river. Several examples in South Africa and the USA are quoted in Gupta and van der Zaag (2008).

Fears of environmental impacts do not always rely on strong scientific evidence. For instance, the Aqua Domitia IBT project (southern France) is strongly opposed by citizens and environmentalists who fear that receiving rivers could be contaminated by PCBs and even radioactive waste leaking into the donor river (the Rhône). Although water quality analyses apparently show that there is no such risk, opponents clearly do not trust the information provided to them and instead advocate the precautionary principle (Commission Nationale du Débat Public 2012).

The environmental impact of IBTs not only restricts the possibilities of constructing new infrastructure, it may also threaten existing ones. In California, the capacity of the Central Valley Project, which transfers water from the Sacramento River to the San Joachim Valley, was reduced by $11 \%$ as a consequence of the Central Valley Improvement Act of 1992. The re-allocation of 985 million $\mathrm{m}^{3}$ to in-stream flow was intended to regenerate salmon runs. Also in California, the Hetch Hetchy aqueduct to San Francisco was strongly contested at the time of its construction by John Muir, a prominent environmental activist. The pipeline, which captures water from the reservoir on the Tuolumne River in Yosemite National Park, is still a source of controversy today and environmentalists continue to request its removal (Ghasseni and White 2007, pp.219-220).

The environmental constraint on IBTs has also been growing due to the recent evolution of water laws and regulations. In the Central Valley example, the decision to reallocate water to the aquatic environment was a direct consequence of the Endangered Species Act (1973). In Europe, the Water Framework Directive is also likely to restrict IBT possibilities, as it strengthens requirements for minimum in-stream flows.

\section{- Increased hostility from donor regions}

In the basin of origin, a loss of water can be perceived as a risk for long-term economic prosperity and quality of life. Communities located in donor basins feel that IBTs unfairly direct economic development away from them, for the benefit of predatory metropolitan areas. As a US stakeholder put it: "when you ship water across the state, you ship jobs as well, for economic development cannot occur without sufficient water supplies". ${ }^{11}$

\footnotetext{
${ }^{11}$ Comment by Ron Cross, posted on 21 March 2010 at: http://onlineathens.com/stories/032110/opi_593391532.shtml
} 
This potential harm has caused most inter-basin transfer proposals to be controversial, often pitting cities benefiting from the transfer against donor rural areas. Conflicts over IBTs are increasingly reported in both developed and developing countries (Cox 1999). For instance, in 1966 the city of Mexico started to extract and transfer groundwater from the Ixtlahuaca valley, $50 \mathrm{~km}$ outside the city. Groundwater tables rapidly declined, depriving the local population from access to a water resource used for drinking water and agricultural irrigation. This generated a strong conflict in the 1970 s and 80s, even threatening the physical integrity of the aqueduct (water robberies and direct attacks) and ultimately led to army intervention (Dyrnes and Vatn 2005).

Conflicts over water transfers may oppose counties, regions, or states. For instance, the Atlanta metropolitan area (Georgia, USA) planned to purchase and transfer water from Tennessee to meet increasing demand. The State of Tennessee opposed the transfer by passing an Interbasin Transfer Act of 2000 (Carver et al. 2011). Atlanta considered other long-distance transfers from two lakes in northern Georgia and from southern Georgia aquifers, but these projects were abandoned as too politically charged. Currently, the city of Atlanta is investigating more local solutions that only involve transfers from one district to another. But these projects too are highly controversial.

This led certain countries or states to tightly regulate transfers to avoid third-party effects. Indeed, in 1996 the water code of California included five articles on 'wheeling', which, among others, protects the rights of third parties impaired by transfers.

\section{- The political dimension of IBTs}

Due to mounting opposition from parts of society, water transfers are increasingly debated in regional, state, or federal political arenas and can even influence the outcome of elections. There are a number of examples showing that political parties can place an IBT as a key issue on their political agenda prior to elections. In Western Australia for instance, the construction of the Kimberley scheme designed to supply the Perth metropolitan area was strongly supported by the LiberalNational coalition during the 2005 election campaign, whereas the Labor Party favored desalination (Ghassemi and White 2007). In Spain, the conservative Aznar government actively supported a National Hydrological Plan during the 2004 elections. At the same time, the European Commission issued two 'reasoned opinions' criticising the lack of appropriate environmental impact and economic evaluation studies. The surprising victory of Aznar's socialist opponent Zapatero allowed the new premier to shelve the huge IBT and launch a desalination plan instead.

As a result, in many non-authoritarian countries only intra-regional transfers can still be implemented, using the regional solidarity argument. In France for instance, a few transfers have still been developed: in the Reunion Island (Indian Ocean) between west and east, in Provence Verdon-St Cassien (SCP); in Languedoc a regional water grid called Aqua Domitia is being considered by the regional bulk water supply company BRL to make up for the loss of the Rhone to Barcelona transfer, but it is hotly debated (see below).

\subsection{INCREASED PUBLIC PARTICIPATION FAVORS OPPOSITION TO IBTS}

Legislation in many countries now requires that consultation with people likely to be affected is carried out before a decision is taken on an IBT. Public consultation may lead to significant changes in 
the design of the IBT project (its route or size) or in the amount of compensation granted to donor regions; it may even lead to a different option or cancellation of the project.

In France for instance, all IBTs above $1 \mathrm{~m}^{3} / \mathrm{s}$ are subject to a public hearing process. The consultation is organised by an independent state agency, the Commission du Débat Public, which nominates a magistrate in charge of organising the public consultation. The objective of the Commission is to ensure a fair debate, during which the voices and arguments of proponents and opponents to the project can be equally heard. At the end of the consultation, the Commission does not provide recommendations related to the project, it only summarises in the most impartial way the views expressed during the consultation. The contracting authority in charge of the IBT project must then prepare a report explaining how it has considered the arguments raised in the debate and present the decision it has made. The whole process ensures maximum transparency in how the decision was taken. Public consultation can represent a significant financial and political cost for the promoters of IBTs.

We illustrate this with the case of the proposed Aqua Domitia IBT project, in southern France. This project consists of extending an existing canal - the Lamour Canal - which diverts water from the Rhône River to supply the Languedoc coastal area. Designed and constructed in the 1960s, the Lamour Canal's main function is to promote development of a diversified irrigated agriculture and the supply of water to coastal tourist resorts. Later on, cities such as Nimes and Montpellier hooked into the pipeline to substitute or complement local resources. The canal is owned by the regional government and operated by BRL, a large semi-public engineering company. The Aqua Domitia Project aims to extend the canal to the west, with the construction of a $2.5 \mathrm{~m}^{3} / \mathrm{s}$ capacity pipeline $130 \mathrm{~km}$ long at a total cost of $€ 280$ million. The pipeline would interlink three main coastal basins (Hérault, Orb, Aude) and supply cities, tourist resorts, and about 7000 ha of irrigated agriculture. Although the agricultural component of the project is marginal (in terms of expected revenues from water sales), the promoters of the project have strongly emphasised this aspect in order to gain political support from rural areas and the agricultural community.

The public consultation consisted of three main phases: the Commission first heard from 92 experts and stakeholders to identify the main issues to be debated; it then organised a series of 13 public meetings in different sub-basins impacted by the project. Five of these meetings focused on thematic issues ${ }^{12}$ and 6 meetings were held to allow all inhabitants to express local views of the problems and identify how an IBT might address these problems. All meetings were filmed and could be followed through the internet. A web site was established to collect comments and suggestions. Stakeholders were offered the option to write position papers which were disseminated by the Commission (Commission Nationale du Débat Public 2012). The debate mobilised experts from water management institutions of the territories concerned by the project and from associations representing environmental protection. Very few lay citizens participated to the meetings, in spite of an intensive communication campaign organised through various media.

The main arguments raised by opponents were the following. The assumptions underlying future water demand forecasts were contested and considered to be biased in favor of the project. The IBT

\footnotetext{
${ }^{12}$ The five thematic issues were the following: 1) the IBT project and urban/economic water demand; 2) the IBT project and irrigated agriculture; 3) IBT and climate change; 4) IBT and alternative solutions; 5) the cost of the project and its impact on water pricing.
} 
would encourage the development of unsustainable water demand from business activities, housing development, and high living standards. The quality of Rhône water was considered as a source of risk for receiving basins, in particular due to the presence of heavy industries (chemical, nuclear) upstream of the IBT intake. Alternative cheaper solutions, such as using local groundwater resources and implementing water conservation measures, were considered to be not sufficiently well investigated.

The public consultation is complicating the decision making process for regional elected politicians and engineers of the water company. First, it adds a significant cost (about $€ 1.2$ million). Second, it offers a platform for opponent to express their views. Third, it weakens the legitimacy of the project if they decide to implement at the end of the consultation; project leaders had to admit that the lack of sufficient existing demand implied the need for public subsidies to fund what would become a regional water grid, which would in turn 'reveal unspoken demands'.

\subsection{REDUCED PUBLIC FUNDING}

IBTs are very costly projects which cannot be fully financed by urban water consumers, unless the water price is raised above what engineers and politicians consider to be the maximum acceptable in social and political terms. Their construction thus relies on subsidies. A strategy to attract subsidies has often been to develop multipurpose IBT projects, supplying urban areas, agriculture, industries, and occasionally providing power generation. In Australia, water transfers supply cities and the mining industry. In France, many recent projects have been marketed as combined urban and agricultural projects - in order to obtain European subsidies from the EU agricultural policy and to obtain political support from the agricultural lobby (which is much more proactive than urban water users). In the present economic crisis, financing projects through an increase in consumer water bills might be considered neither socially acceptable nor politically feasible.

\subsection{WHY DO IBTS REMAIN SO ATTRACTIVE?}

In the western US, the development of new IBT projects is no longer favored because of their high cost compared to alternative solutions and their environmental and social impacts. Water planners increasingly rely on water conservation programs, water trading (purchase from irrigation districts), desalination, and waste water recycling. Conversely, IBTs are still considered by engineers and politicians in a number of European countries (e.g. France, Spain) but also in developing countries. What can explain the preference for multi-million euro water schemes when cheaper water demand management alternatives exist? Analysing the interests at stake for the different actors involved in such decisions can help answer this question. A preference for large scale expensive infrastructure projects can be said to reflect the existence of powerful coalitions between politicians, engineers, and financial actors who wish to protect political and economic interests.

From a political perspective, the choice of an inter-basin transfer solution is likely to yield significant benefits for locally elected representatives. When supporting an IBT project, they typically appear as "providers of a life-giving resource that enhances health, security and prosperity" (Gumbo and van der Zaag 2002). Since such large projects are often subsided by government agencies or international donors in developed countries, they can also claim to have attracted external funds to support the development of the regional economy, in particular in the case of multi-purpose projects supplying agriculture, industry, and the population. Leaving their personal mark in local historical records can 
be an additional motive: there are plenty of canals and pipelines around the world that bear the name of the local politician who initiated the project. By contrast, water demand management programs are perceived as constraints on the population, so there is little benefit for politicians to support this type of action. It is much more comfortable for a politician to be seen as finding ways to meet people's water demand rather than trying to change their behavior and infringe on their freedom to consume what they consider a basic good. Moreover, because the money spent on water conservation programs does not materialise as a tangible asset, it may be perceived as a less efficient use of public funds than the construction of a pipeline. However, in the end, large hydraulic schemes bring more benefits to governments in search of legitimacy than to their countries' economies (Allan 2002; Molle and Berkoff 2009)

From a technical perspective, engineers in charge of urban water schemes may prefer to build a water supply infrastructure than implement demand management because the infrastructure gives a prompt and long lasting solution to the water deficit problem. By contrast, investing in water conservation is considered more risky since the behavior of water users might change unexpectedly in the future. Technical staff are thus reluctant to engage in a strategy which does not allow them to certify that demand will be satisfied under all future circumstances. They may feel that accepting this risk undermines their professional legitimacy. Moreover, engineers tend to prefer large one-shot projects that they eventually can claim prowess for than immerse themselves in demand management projects, which may require many small and technically diverse engineering inputs, the involvement of non-engineering technicians such as economists (design of water conservation oriented rates), and communication specialists (awareness raising campaigns). The latter somehow implies losing control over a water system that they have been accustomed to operate by themselves.

From an economic perspective, politicians and managers alike generally prefer projects entailing high initial investment costs; these can be subsidised, whereas operation and maintenance costs are not eligible for public subsidies. This is a strategy that allows water prices to be kept at a lower level, with obvious political benefits. Also, engineering firms have a strong interest in supply-oriented options such as IBTs, which generate significant work and can be added to their list of technical references. Large scale projects may also be favored by financial actors, such as banks and international donors, because it allows them to meet their lending objectives. In some nations, individuals can obtain personal benefits (bribes) by supporting the construction of infrastructure (Davis 2004).

The existence of a powerful coalition supporting IBTs against a preferable alternative option is nicely illustrated in a case study conducted in the city of Mutare, Zimbabwe (Gumbo and van der Zaag 2002). The study showed that the choice of the pipeline option allowed the political and economic interests of the three main actors to align. Similar conclusions can be reached in a case study of Mexico City's water supply (Dyrnes and Vatn 20005). These authors conclude that the IBT solution was preferred to unpopular regulation and water conservation policies because it represented a relatively quick solution, popular with public opinion and Mexico City authorities. 


\section{Looking ahead: using existing IBTs for reallocating water}

For the different reasons set out in the previous section, fewer large IBT schemes are expected to be constructed in the 21rst century than in the previous one. Moreover, it is likely that in the future existing IBT schemes will be used to increase flexibility in water allocation over space and time. As conjunctive use management approaches gain support, IBTs will be operated in conjunction with aquifer storage and recovery schemes. It is also likely that IBTs will support the development of emerging water markets, particularly during drought years.

\subsection{IBT AND AQUIFER STORAGE AND RECOVERY (ASR)}

Because most IBTs have been sized to meet demand during drought years, their capacity is not fully used in normal and wet years, producing a significant cost burden. One solution to improve the financial sustainability of these schemes consists in using the excess capacity in normal years to store water in depleted aquifers. Artificial recharge can be performed during wet years, using infiltration ponds or deep injection wells. Stored water is then extracted in dry years when surface water is scarce and the full IBT capacity used. Conjunctive management improves water supply reliability. This strategy, referred to as conjunctive management, combines the use of a transport and a storage infrastructure to bridge the gap between water demands and available resources over time. Such conjunctive management is already implemented in Arizona, where Colorado water transferred with the Central Arizona Project is used for recharging groundwater in the region of Phoenix and Tucson. ${ }^{13}$ Similarly, water from the California State Water Project is also used to recharge groundwater in the central valley (Kern county, ${ }^{14}$ Santa Clara valley). The combine use of IBTs and ASR however requires that a specific institutional framework - water banking - be developed for tracking water rights and ensuring that users storing excess imported water during some years can retrieve it during drought years.

\subsection{FROM PIPELINE TO GRID}

While engineers and financiers will probably move away from large IBTs in the coming decades, existing projects are likely to continue to develop into water grids at the regional level. Here again, the rationale leading to the development of grids is to increase the flexibility of supply over time and space through physically linking production and storage infrastructures. Grids enable water to be moved in several directions - from where it is available to where it is required. The best historical case of a regional water grid is California, where water can be moved from north to south and vice versa through the State Water Project in the central valley, and via other IBTs from east to west, including the Colorado transfer. It is only after a sufficient number of links came into being that it was possible to imagine water trading. We have already pointed out that the potential third-party impacts, which add to the cost of transfers, usually limit the volumes exchanged (e.g. the IID in San Diego, see below).

Australian cities responded to the 10-year long recent drought by developing such grids. The Queensland government is spending A\$ 9 billion on a South East Queensland water grid, consisting of

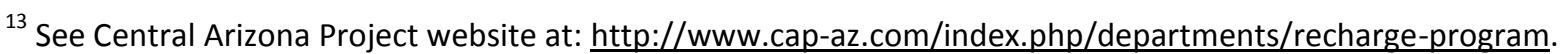

${ }^{14}$ See Water Association Kern County website at http://www.wakc.com/index.php/water-overview/sources-ofwater/87-water-banking
} 
$450 \mathrm{~km}$ of pipelines, two new dams, a desalination plant, and three advanced water treatment plants to deliver 350 million $\mathrm{m}^{3} / \mathrm{yr}$ additional water. It also includes greater reliance on recycled water. A similar project in the State of Victoria consists of creating another such grid, with six major links under construction. The project includes new water transfers such as the Sugarloaf Interconnector that would take water to Melbourne from the Goulburn River, a tributary of the water-stressed River Murray (Pittock et al. 2009)

In the UK, the Environmental Agency of England and Wales recognises that there may be further opportunities for developing greater linkages between existing water company systems, and for sharing of water resources to gain some of the same benefits expected of large-scale transfers (Environment Agency England and Wales, 2011). However, a projected national water grid was shelved by the national regulator which instead pushed for conservation and leak control. And the idea of common carriage, i.e. separating the management of infrastructure and the production and sale of water, as is the case for rail and electricity, was also turned down as a public health precaution.

\subsection{WATER TRANSFER INFRASTRUCTURES AND TRADING IN A MATURE WATER ECONOMY}

In recent years, large-scale water transfer infrastructure has increasingly been used for reallocating water from some water right holders to others, based on voluntary agreements. IBTs can therefore support the development of water trading, which can in theory ensure improved water efficiency, particularly during drought conditions. Examples come mainly from the western states of the USA, Australia, and, more marginally, Spain.

In Southern California, the Imperial Irrigation District (IID) is the 'first in time' and largest water right holder in the Colorado basin ( 3.2 billion $\mathrm{m}^{3}$ out of the 5.4 billion allocated to California). IID receives its water from the All American Canal (constructed in 1942) and distributes it to farmers through unlined distribution canals, where significant water losses occur. In the late 1980s, IID was compelled by the US Bureau of Reclamation to improve the technical efficiency of water use through lining distribution canals. Water conservation potential was estimated at about 400 million $\mathrm{m}^{3}$. IID was then approached by the Metropolitan Water District of Southern California (MWD) who was interested in providing support for the lining, and recovering and transferring part of the water conserved. An agreement was signed between MWD and IID in 1989 for a 35-year term. After implementing conservation projects, IID reduced its water abstraction from the Colorado River at Imperial Dam, while MWD increased its pumping from the Colorado at Parker Dam and transferred the water to the Los Angeles area, using the $380 \mathrm{~km}$ long Colorado River Aqueduct. Later on, San Diego came into the re-allocation game, and requested a direct transfer of IID water for its own use (Pincetl 2012).

In 2003, after being accused of not using water efficiently, and under threat of the California Water Resources Board to get its huge share reduced, IID signed another transfer agreement with the San Diego County Water Authority (SDCWA), by which they agreed to transfer annually 247 million $\mathrm{m}^{3}$ of conserved water for a term of 75 years. IID implemented additional water conservation measures at the farm level, and with other projects the volume of transferred water progressively increased so as to reach a maximum after 10 years. However, even though the SDCWA had gone through this lengthy process to acquire more independence vis-à-vis MWD (whose rival Los Angeles interests superseded), it turned out that the best economic solution was to use existing MWD aqueducts to re- 
allocate regional water and divert it to San Diego and to another irrigation district (which held senior rights on the water). Moreover, the environmental movement was also able to make sure that some of the water would help maintain the level of the Salton Sea (a saline lake between IID and San Diego which is an important stop on bird migration routes) (Pincetl 2012).

In Spain, two large IBTs, which were primarily constructed to meet growing urban and agricultural water demands in coastal areas, are now being used for transferring water based on voluntary exchanges between right holders. The first case is the Tagus-Segura IBT through which intensive fruit and vegetable growers in the Segura basin purchase water from more extensive farmers in the Tagus basin. The second is the Negratin-Almanzora connecting the upper Guadalquivir basin to the Andalucian coastal basins. This $120 \mathrm{~km}$ long pipeline was recently used to transfer water purchased by an Almanzora drinking water company in Andalucía to rice growers in the Guadalquivir delta (Garrido et al. 2013).

IBT infrastructure can also facilitate the development of option contracts between agricultural users and urban areas. In a typical option contract, an urban agency pays an option premium for the right to purchase water at some point in the future, if climate turns out to be dry. Option contracts do not imply the transfer of ownership, so right-holders retain access to the water allotment when the option is not exercised. This type of agreement was established in California in about 1994. In 2003, the MWD and Paolo Verde irrigation district signed an option agreement with a 35-year term by which MWD can call on from 25,000 to 110,000 acre-feet (31 to 135 million $\mathrm{m}^{3}$ ) each year. The irrigation district receives a one-time fee of $\$ 3170$ for each acre participating in the program and $\$ 600$ for each acre that is fallowed during the program. There were 15 such contracts signed between 2003 and 2008 in California (Hansen et al. 2008; Tomkins and Weber 2010). Overall, option contracts represent efficient risk management instruments and they offer new perspectives for using existing IBT infrastructure.

\section{Conclusion}

Large hydraulic projects have underlain the success of ancient civilizations, and they are part of humankind's water culture. However, most of them have been confined to a single river-basin. The aqueducts of the Roman Empire are a notable exception, and it remains fascinating that the Romans spent so much effort to build such impressive and long-lasting hydraulic architecture, but then, in the end, to transfer so little water. It would be interesting to link this with the economy of the time, e.g. looking at the slavery factor. In our capitalist economy, the value of labor and the depreciation of capital over time make such projects impossible to finance. And because water is heavy, hydraulic infrastructure usually comprises specific assets with high investment costs and slow technical depreciation.

Yet in order to provide clean water to cities, the idea resurfaced of transferring water over long distances, an idea that returned in the classical period and rose during the 19th and 20th centuries. Additionally, the invention of the steam engine, of sealed pipe junctions, and also of tight-closing faucets, made it possible to raise water or build siphons and develop IBTs at an unprecedented scale.

However, at the turn of the 20th century, water treatment was invented. This allowed a reduction in the initial investment cost by increasing operation and maintenance costs. In turn, this new 
engineering based on water treatment and sanitation made it possible to extract water from nearby surface water; it made urban water much more a local affair, and shifted the burden of finance from the state or rich entrepreneurs to the customers. From that point on, control of water volumes became essential, and this did not favor large IBTs, where the bigger the flow, the smaller the marginal cost.

Paradoxically, IBTs still fared very well in the colonies, and later in developing nation-states, for intensive agriculture: the motto after WW2 was multipurpose water projects for global economic development, meaning that industrial and urban water users would indirectly subsidise agriculture. But as soon as environmental impacts were translated into dollars, and the global economy became less confident in the future (thus increasing interest rates), many IBTs were weakened. Their future would have been better assured if they had been re-integrated into some regional water resources management scheme, perhaps associated with the conjunctive use of ground water and surface water. Large IBTs have been frequently associated with the power of upper layers of government, especially centralised ones. At a time when multi-level governance is on the global agenda, it becomes difficult to believe that transferring large quantities of water suffices to improve humankind's welfare: it has to be combined with less conventional technologies and other institutional designs.

\section{Acknowledgements}

J. D. Rinaudo would like to thank Bruno De Grissac for his contribution to this paper through several informal discussions on water conservation related issues. He also acknowledges support from BRGM (scientific program 30) for preparing this chapter.

\section{References}

Allan, J. A. (2002). The Middle East water question: Hydropolitics and the global economy. London and New York: I. B. Tauris.

Beecher, J. (2012). The ironic economics and equity of water budget rates. Journal of the American Works Association, 104, 73-81.

Blomquist, W., Schlager, E. \& Heikkila, T. (2004). Common waters, diverging streams: Linking institutions and water management in Arizona, California, and Colorado. Washington DC: Resources for the Future Press.

Carver, W. B., Cole, D. \& Wingate, C. A. (2011). Tapping the Tennessee River at Georgia's northwest corner: a solution to North Georgia's water supply crisis. Proceedings, Georgia Water Resources Conference, Atlanta.

Cohen, R., Nelson, B. \& Wolf, G. (2004). Energy down the drain: the hidden costs of California's water supply. Oakland, CA: Natural Resource Defense Council and Pacific Institute.

Commission Nationale du Débat Public (2012). Compte rendu du débat public Aquadomitia 15 septembre - 29 décembre 2011. Paris: CNDP, p. 182. 
The final version of this paper is published in : Understanding and managing urban water in transition. Edited by: Grafton Q., Daniell K.A., Nauges C, Rinaudo J-D. \& Wai Wah Chan N. (2015) Springer.

Cox, W. E. (1999). Interbasin water transfer. Proceedings of the International Workshop. Paris: IHP, UNESCO.

Davis, J. (2004). Corruption in public service delivery: experience from South Asia's water and sanitation sector. World Development, 32, 53-71.

Dyrnes, G. V. \& Vatn, A. (2005). Who owns the water? A study of a water conflict in the Valley of Ixtlahuaca, Mexico. Water Policy, 7, 295-312.

Environment Agency of England and Whales (2011) Large-scale water transfers: position statement. https://www.gov.uk/government/uploads/system/uploads/attachment data/file/297318/geho0811 btvr-e-e.pdf

Garrido, A., Rey, D. \& Calatrava, J. (2013). Water trading in Spain. In L. De Stefano (Ed.), Water, agriculture and the environment in Spain: can we square the circle? Madrid: Botín Foundation, pp. 205-216.

Ghaffour, N., Missimer, T. M. \& Amy, G. L. (2013). Technical review and evaluation of the economics of water desalination: current and future challenges for better water supply sustainability. Desalination, 309, 197-207.

Ghassemi, F. \& White, I. (2007). Inter-basin water transfer: case studies from Australia, United States, Canada, China and India. Cambridge: Cambridge University Press.

Gleick, P. (2003). Global freshwater resources: soft-path solutions for the 21st Century. Science, 302, 1524-1528.

Gleick, P. H., Haasz, D., Henges-Jeck, C., Srinivasan, V., Wolff, G., Kao Cushing, K. \& Mann, A. (2003). Waste not, want not: The potential for urban water conservation in California. Oakland: Pacific Institute.

Gumbo, B. \& van der Zaag, P. (2002). Water losses and the political constraints to demand management: the case of the City of Mutare, Zimbabwe. Physics and Chemistry of the Earth, 27, 805813.

Gupta, J. \& van der Zaag, P. (2008). Interbasin water transfers and integrated water resources management: where engineering, science and politics interlock. Physics and Chemistry of the Earth, $33,28-40$.

Hallegate, S. (2009). Strategies to adapt to an uncertain climate change. Global Environmental Change, 19, 240-247.

Hansen, K., Howitt, R. \& Williams, J. (2008). Valuing risk: options in California water markets. American Journal of Agricultural Economics, 90, 1336-1342.

Kenney, S. D., Goemans, C., Klein, R., Lowrey, J. \& Reidy, K. (2008). Residential water demand management: lessons learnt from Aurora, Colorado. Journal of the American Water Resources Association, 44, 192-207.

Lapuente, E. (2012). Full cost in desalination. A case study of the Segura River Basin. Desalination, $300,40-45$

Miller, W. G. (2006). Integrated concepts in water reuse: managing global water needs. Desalination, $187,65-75$.

Molle, F. \& Berkoff, J. (2009). Cities vs. agriculture: a review of intersectoral water re-allocation. Natural Resources Forum, 33, 6-18.

National Academy of Sciences (2012). Water reuse: Potential for expanding the nation's water supply through reuse of municipal wastewater. Washington DC: NAS. 
Pincetl, S. (2012). Urban water conflicts in the Western US. In Barraqué, B. (Ed.), Urban water conflicts. Paris: Taylor \& Francis, pp. 237-246.

Pittock, J., Meng, J. \& Chapagain, A. K. (2009). Interbasin water transfers and water scarcity in a changing world: a solution or pipedream? Frankfurt am Main: WWF Germany.

Pouget, L., Escaler, I., Giuiu, R., Mc Ennis, S. \& Versini, P.-A. (2012). Global change adaptation in water resources management: the water change project. Science of the Total Environment, 440, 186-193.

Rinaudo, J.-D., Neverre, N. \& Montginoul, M. (2012). Simulating the impact of pricing policies on urban water demand: a Southern France case study. Water Resources Management, 26, 2057-2068.

Rinaudo, J., Maton, L. \& Caballero, Y. (2010). Cost-effectiveness of a water scarcity management plan: considering long term socio-economic and climatic changes. Options Méditerranéennes, 95, 183-190.

Shirley-Smith, C., Cheeseman, C. \& Butler, D. (2008). Sustainability of water management in Zaragoza city. Water and Environment Journal, 22, 287-296.

Tomkins, C. \& Weber, T. (2010). Option contracting in the California water market. Journal of Regulatory Economics, 37, 107-141.

Tortajada, C. (2006). Water management in Singapore. International Journal of Water Resources Development, 22, 227-240.

Vedachalam, S. \& Riha, S. J. (2012). Desalination in northeastern U.S.: lessons from four case studies. Desalination, 297, 104-110.

Waterwise (2009). Preston water efficiency initiative. London: Waterwise.

Zekri, S., Ahmed, M., Chaieb, R. \& Ghaffour, N. (2013). Managed aquifer recharge using quaternarytreated wastewater: an economic perspective. International Journal of Water Resources Development, 30, 246-261.

Zhou, Y. \& Tol, R. S. J. (2005). Evaluating the costs of desalination and water transport. Water Resources Research, 41 (W03003). 